\title{
貝毒に関する研究の現状と課題*
}

\section{大島 泰 克}

\section{1.はじめに}

通常食用となっている二枚貝が突然に毒化して，そ れを食べた人が中毒を起こすことがある。この毒は二 枚貝自体が生産するのではなく，有毒の単細胞藻類か ら食物連鎖を通して二枚貝に移行，蓄積される。この 貝毒と総称されているものには原因となる藻類, 毒の 化学的性状, 作用を異にする 4 グループがあり, 食品 衛生上のみならず, 産業上も大きな劦威となっている。 ここではそれらについての基礎的な説明と最近の話題 を述べる。

\section{2. 麻痺性貝毒}

\section{1 発生状況}

貝毒のなかでもっとも古くから知られているもの で，アメリカインディアンの伝承にもあるが，1790年 にロシアの探険隊がアラスカでイガイを食べて 100 名 が死亡したのが最初の記録とされている。症状が神経 麻瘏を主徵とすることから麻痺性貝中毒（paralytic shellfish poisoning) と呼ばれ，死亡率が高いのが特徵 である。わが国では, 昭和 23 年愛知県豊橋市でアサリ により12名の患者が出て以来，これまでに 7 件146名 (うち死亡 4 名)の患者の発生をみている。地域的には 北海道から九州にいたる各地で二枚貝の毒化が起きて いるが，特に東北，北海道では重要な産業であるホタ テガイが毎年のように長期の出荷規制を受けることか ら経済的被害が大きい。1980年代以降わが国でも監視 体制が整備されつつあり，この貝毒による食中毒はほ とんど発生していなかったが，1989年 7 月に青森県で



Yasukatsu Oshima
昭和 44 年 東京大学理学部化学科卒業
49 年 同大学院博士課程修了
50 年 ロードアイランド大学研究員
52 年 東北大学農学部助手
54 年 同助教授

農学博士
〔趣 味〕 ラグビー

* Shellfish Poisoning: An Overview, 1989年10月 2 日受理
定置網掃除の副産物であるムラサキイガイが原因で, 死者を含む食中毒が発生している。このような主要生 産種以外の二枚貝による事故をいかに防ぐかが今後の 問題とされる。

世界的にみると古くから麻痺性貝毒の出現が知られ ているアメリカ大陸東西海岸，ヨーロッパ等北半球の 冷水域では1976年にスペインから輸出されたムラサキ イガイでョーロッパ各国で多数の食中毒患者が発生し て以来，大規模な事故は起きていない。しかし，近年， ボルネオ, フィリピン, グアテマラ等の熱帯, 覀熱帯 地域で患者数百人を超える大規模な事件が多発してい る。これらは有毒渦鞭毛藻の大規模な赤潮に伴って発 生し, 監視体制, 情報伝達網の整備が難しい地域で起 こることから被害が大きくなる傾向がある。また，台 湾, 韓国, ホンコン, オーストラリア,メキシコ等, これまで麻痺性貝毒の記録のなかった地域から中毒の 発生あるいは二枚貝の毒化が報告されて和り，污染海 域は広がる傾向にある。

\section{2 毒化原因生物}

二枚貝の毒化原因としては数種の渦鞭毛藻（dinoflagellate) が知られている。最も古くから知られて抏 り, 研究の進んでいるのは Alexandrium 属であるが, かつてこれは Gonyaulax 属の "tamarensis group” に まとめられていた。新しい属名について分類学者の間 で見解が一致せず，Protogonyaulax，Gessnerium 等文 献の記載にも混乱が続いていたが，1989年 6 月にス ウェーデンで開催された第 4 回国際海洋有毒植物プラ ンクトン学会に扣いて渦鞭毛藻分類の専門家多数を集 めた討論が行われ, 今後統一してAlexandrium を使用 することで合意に達している。Alexandrium は北米， ヨーロッパに拈ける主要原因種であるが, 日本では $A$. tamarense と A. catenellaの 2 種が毒化原因として確 認されている1)。分布域は重複するものの一般に前者 が北日本, 後者が西日本に和ける主要な毒化原因とさ れてきた。しかし，1988年10１2月にはA. catenellaが 北海道噴火湾に出現してホタテガイの毒化を起こした り，1988，1989年の 6〜 7 月には茨城県沿岸で同種の 大規模な赤潮が発生するなど複雑化している。熱帯域 に打いて多発している麻瘏性貝毒は，タイなどの一部 で報告されているA. cohorticula d) 除いて, 
Pyrodinium bahamense var. compressa に起因してい る。本種は広大な海域で赤潮を形成し, 二枚貝のみか プランクトンフィーダーの魚をでも毒化させることが ある。また，最近我々によって毒生産能が確認された Gymnodinium catenatum は上記 2 属が有殸の渦鞭毛 藻であるのに対し，無殼であるのが特徴である。1976 年のスペインの毒化以来第 3 の有毒グループとして, メキシコ(太平洋岸), オーストラリア $(\text { タスマニア })^{3)}$, 日本 (山口県仙崎) $\left.{ }^{4}\right)$゙どで散発している。無殼のため Alexandrium 属などに用いられる固定法では失われ ることがあるので，これまでのプランクトン調査で見 過ごされてきた可能性もあり，今後注意を要する種類 である。

形態学的に同一種に分類された中には出現環境を大 きく異にするものや，無毒あるいは毒組成の大きく異 なる株があり, 同一種内に多系群が存在することを示 している5)。このことは増殖要因の解明を目的として 原因渦鞭毛藻の生理生態研究を実施する際に, 問題を 複雑かつ難しくしている。また，毒生産能（1 細胞当 りの毒力）は培養条件によって大きく変動するが，そ の機構あるいは毒の渦鞭毛藻内での機能は未だ解明さ れていない。

Alexandrium 中心として上記の渦鞭毛藻の生活 史が最近明らかにされつつある(図 1)。二枚貝の毒化 に関与するのは無性的に細胞分裂を繰り返して増殖す る遊泳細胞であるが，形態的には区別できない 2 交配 型からなる。両者は接合したのち遊泳力を失い，休眠 接合子(シスト)となって海底に沈む1)。G. catenatum $^{6)}$ とP. bahamense var. compressa $a^{7}$ といてもシストが 発見されて赫り，注济同様の生活史を有すると考克ら れている。シストは耐久性があり, 次年度遊泳細胞発 生ひいては二枚貝毒化の種となる。従って, 海底の堆 積物中のシストの有無を調査することで，その海域の 有毒渦鞭毛藻出現を予測できる。また, シストは有毒 鞭毛藻の分布域の拡大にとって重要子考光られてい る。特にバラスト水中に混入したシストが貨物船に よって運ばれ，毒化域の拡大の原因となる可能性が指 摘され，対策が求められている。

二枚貝の毒化には関連しないが淡水産の藍藻 Aphanizomenon fros-aqua の特殊な系群が麻痺性貝毒 を生産することが明らかにされている。また，最近児 玉らによって麻痺性貝毒を生産するバクテリアが単離 されて和り, 渦鞭毛藻の毒素生産との関連が注目され ている ${ }^{8)}$ 。熱帯域の珊瑚礁に生息するオオギガニ科の カニは高濃度で麻痺性貝毒を含むことが知られている が, 我々はさきにカニの慨となる紅藻モサズキから麻 瘏性貝毒を検出した ${ }^{99}$ 。これも海藻に付着あるいは共

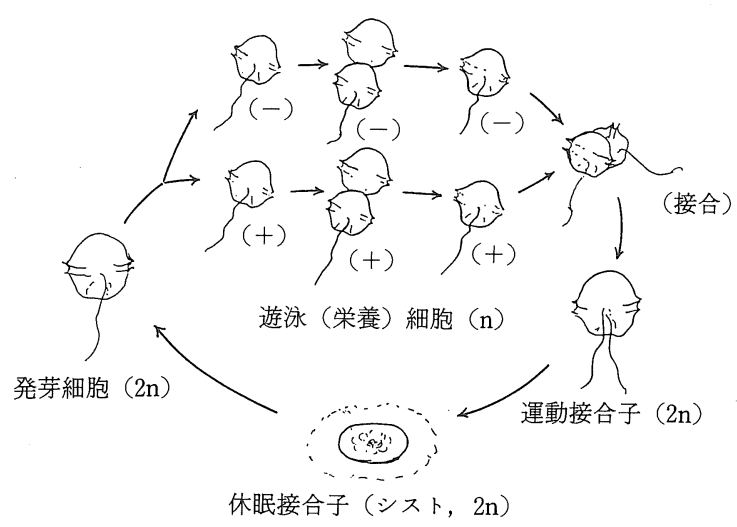

図 1 Alexndrium 属の生活史 ( $\mathrm{n}, 2 \mathrm{n}$ は核相,,+ , 一交配 型を示す)

生しているバクテリアによる可能性が高い。

\section{3 麻痺性貝毒の性質, 構造, 分析法}

1950年代にアラスカバタークラムから単離され, 学 名 Saxidomus giganteus にちなみサキシトキシンと命 名された主要毒の構造は，1975年に明らかにされた。 試料の入手しやすさから生物試験による定量法の設定 をはじめとして毒物学, 薬理学など初期の研究はサキ シトキシンを対象にして行われてきた。しかし，1975 年以降，ゴニオトキシン $1 \sim 4$ ，ネオサキシトキシン をはじめとするサキシトキシン同族体が次々に発見さ れ，現在までに図 2 に示す18の成分の存在が確認され ている。二枚貝中では汪とんぞの場合，数成分の混合 物として存在し, 出現した原因プランクトンによって 組成が異なることが多い。いずれの成分も水溶性で, 中性や微酸性溶液中では加熱に対して安定であるが, アルカリ性では不安定である。サキシトキシンの毒性 は $1 \mathrm{mg}$ でマウス 5,500 尾を殺すほどで, フグ毒のテト ロドトキシンに匹敵する。毒性の発現はいずれも神経 細胞などの $\mathrm{Na}$ チャンネルの選択的な遮断による。毒 力は成分によって異なり，ゴニオトキシン $1 \sim 4$ など のカルバメート型成分はほぼサキシトキシンに等しい が，脱カルバモイル型はその50 60\%の強さである。 また，ゴニオトキシン $5,6,8$ などの側鎖カルバモイ ル基がスルフォン化された毒群はカルバメート型毒の 数分の 1 から十数分の 1 極めて低い。しかし，これ らスルフォカルバモイル毒群は加熱すると加水分解を 受け, $\mathrm{pH}$ によって高毒性のカルバメートあるいは脱 カルバモイル型成分に変換される。各地の G. catenatum や北海道，茨城に出現したA. catenellaによって毒化 した二枚貝はこれらの低毒力成分を多量に含むことが 明らかになり5)，ヒトの消化管内あるいは食品加工中 の変換の可能性を含め, 今後食品衛生学的にどう評価 
するかが問題となっている。

現在貝毒の監視はマウスに対する致死毒性を利用し た試験法によって行われている。マウス毒性試験法は 簡便であるが動物の入手，管理が大変であり，分析の 特異性, 精度にも問題がある。また, 人道的見地から この試験法を認めない国もあり，生物試験に代わる分 析法が求められていた。我々は麻痺性貝毒をアルカリ 中で酸化すると芳香化して蛍光物質に変換する特異的 な性質を利用して，ポストカラム反応型の蛍光一高速
液体クロマトグラフィー法を開発した ${ }^{10)}$ 。図 3 に装置 の模式図和よび分析例を示す。逆相分配型カラムとア ルキル硫酸またはアルキルアンモニウムを含む移動相 の組み合わせによるイオン対クロマトグラフィーで毒 の分離を行ら。酸化剂としては過ヨウ素酸を用い, 蛍 光強度を上げるためにモニターに入る前に酢酸で $\mathrm{pH}$ を調整する。高感度で毒が検出でき，実際の試料につ いて行った分析でもマウス毒性試験と極めて良好な相 関が得られ，麻痺性貝毒の監視に実用可能であること

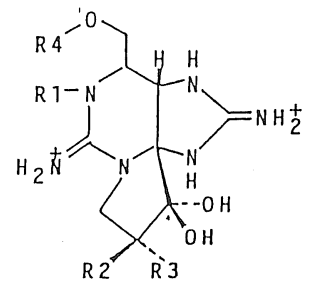

$\begin{array}{llllll}\mathrm{R} 1 & \mathrm{R} 2 & \mathrm{R} 3 & \mathrm{R} 4: \mathrm{CONH}_{2} & \mathrm{R} 4: \mathrm{CONHSO}_{3}^{-} & \mathrm{R} 4: \mathrm{H} \\ \mathrm{H} & \mathrm{H} & \mathrm{H} & \mathrm{STX} & \mathrm{GTX} 5 & \text { dcSTX } \\ \mathrm{OH} & \mathrm{H} & \mathrm{H} & \text { neoSTX } & \text { GTX6 } & \text { dcneoSTX } \\ \mathrm{OH} & \mathrm{H} & \mathrm{OSO}_{3}^{-} & \mathrm{GTX} 1 & \mathrm{C} 3 & \text { dcGTX1 } \\ \mathrm{H} & \mathrm{H} & \mathrm{OSO}_{3}^{-} & \mathrm{GTX} 2 & \text { epiGTX8 } & \text { dcGTX2 } \\ \mathrm{H} & \mathrm{OSO}_{3}^{-} & \mathrm{H} & \mathrm{GTX} 3 & \mathrm{GTX} 8 & \text { dcGTX3 } \\ \mathrm{OH} & \mathrm{OSO}_{3}^{-} & \mathrm{H} & \mathrm{GTX} 4 & \mathrm{C} 4 & \text { dcGTX4 }\end{array}$

図 2 麻痺性貝毒の構造

STXはサキシトキシン, GTXはゴニオトキシン, dcは脱カルバモイルを示す.
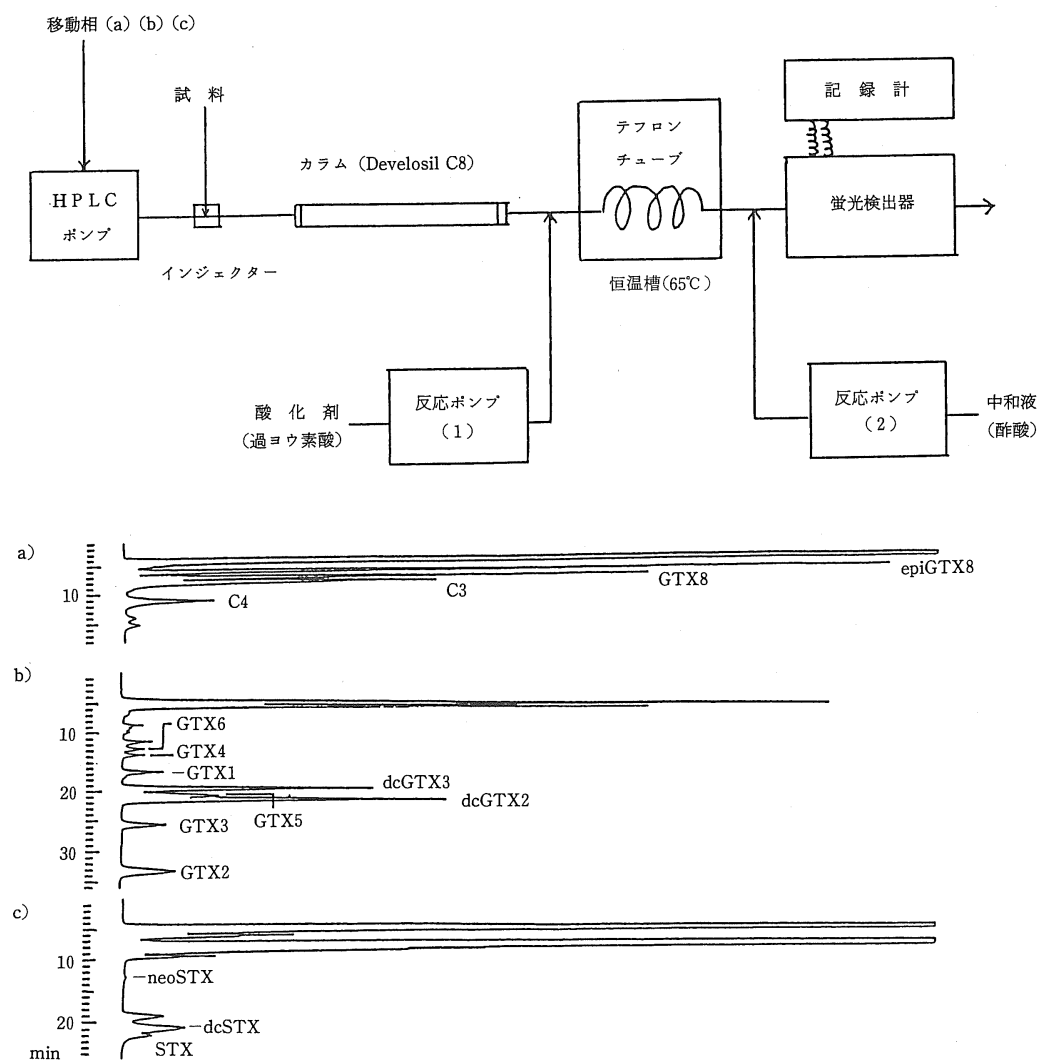

図 3 麻痺性貝毒分析装置の模式図とクロマトグラム

毒の塩基性により 3 グループにわけ，異なる移動相を用いて分析する. 分析例としてタスマニア産ムラサキイガイを示 す。各クロマトグラムは試料 $2.5 \mathrm{mg}$ 相当の抽出液の注入による. 
を明らかにした。今後この装置を貝毒監視の目的で普 及させるには外部標準として必須の精製毒の供給をい かにするかが問題となろう。な挔, 本装置は 1,000 細胞 以下の試料で全組成分析が可能なほど高感度であるこ とから, 今や原因渦鞭毛藻の研究には必須となってい る。新しい麻痺性貝毒生産生物の追求, 毒組成分析に よる系群判別，さらにほとんど解明されていない二枚 貝の毒の蓄積, 代謝機構等の研究にも役立つものと期 待される。

な损，麻疩性貝毒の定量法として抗原抗体反応を利 用した免疫的方法が開発されつつある。毒と蛋白との 複合体を抗原としてモノクロナール抗体がつくられ, サキシトキシンの測定キットも市販されようとしてい る。しかし比毒性の大きく異なる多数の毒が混在する 実際の試料での実用性は確立されていない。

\section{3. 下痢性貝毒}

\section{1 発生状況}

下㢉性貝中毒 (diarrhetic shellfish poisoning) は古 くより東北地方などで発生していたと考えられるが, 1976年 6 月に発生したムラサキイガイを原因とする食 中毒を契機として安元ら ${ }^{11}$ によって発見された比較的 新しい型の食中毒である。しかし，これまでに国内で 1,200名，ヨーロッパでも8,000名を超觉る患者の発生 をみて扣り，麻痺性貝毒をはるかに上回っている。中 毒の主な症状は, 消化器系の障害で, 下痢, 扮う吐, 腹痛が顕著である。これらの症状に加光て中毒の発生 が夏期（6〜9月）に限られることから，腸炎ビブリ オと誤認されやすいが, 新鮮な二枚貝や加熱調理品で も発生し，発熱症状を伴わないことから区別できる。 原因毒は, 熱安定性であり, 通常の加熱調理で破壞さ れることはない。死亡事例はない。

貝の毒化は, 麻痺性貝毒之同様で, 渦鞭毛藻の季節 的な発生によって起こる。ホタテガイ, ムラサキイガ イが毒化の激しい海域と養殖域が一致しており, 消費 量も多いことから, 食中毒の原因となることが多いが, アサリをはじめとしてほとんどの二枚貝が毒化する。

しかし, 毒は中腸腺に局在しているために, ホタテガ イのように除去できるものは中毒を回避できる。

国内で毒化の確認された海域は, 北海道から九州の 沿岸に散在しているが, 程度の激しい海域は, 陸奥湾, 三陸海岸, 噴火湾, オホーツク沿岸などである。スペ イン, フランス, オランダ, ノルウェーなどヨーロッ 只国, チリ等でも発生がみられ, 熱帯域でもその存 在が疑われている(12)。

\section{2 毒化原因生物}

毒化原因についても中毒発見当初から安元らによっ
て精力的に進められた。東北地方の二枚貝の毒力推移 と出現プランクトンの変動を精密に追跡し，さらに大 きさ別に分画したプランクトン試料の毒力と構成種の 解析から渦鞭毛藻のDinophysis fortii が原因と推定し た ${ }^{13)}$ 。乙かし, 本種の培養は極めて難しく最終的な毒生 産の確認は, 高感度の化学的分析法の開発を待たなけ ればならなかった。下㢉性貝毒の主要毒であるディノ フィシストキシン-1拉よびオカダ酸が蛍光一液体ク口 マトグラフィーで検出できることを示したLee ら ${ }^{131}$ は，顕微鏡下で純粋にして集めたプランクトンを分析 に供し, D. fortii をはじめ, D. accuminata, D. mitra, D. acuta, D. rotundata, D. norvegica 等多数の Dinophysis 属に下痢性貝毒を確認するにいたった。をた, 同 一種でも地域により生産する毒の組成が異なることも 明らかになっている。さらにペクテノトキシンも D. fortii 起源であることが示されている。D. fortii は20 cells $l^{-1}$ 程度の低密度の出現で二枚貝を毒化させる。

被害の大きい東北, 北海道では D. fortii の分布, 動 態についての調査が各県の水産試験場の協力で実施さ れている。通常 4 月に日本海側で最初に観察され，5 月には陸奥湾ついで太平洋岸に移り, 高密度域は北か ら南にかけて順次移動する。その出現状況は対馬暖流 と津軽暖流および津軽暖流に端を発する沿岸南下流に 対応し，その関連に興味がもたれている1)。Dinophysis も細胞分裂で増殖するが, 通常の栄養塩添加海水で培 養できない。最近東京水産大学の石丸は D. fortii がク ロロフィルを持たず，渦鞭毛藻に通常見られないフィ コシアニン特有の蛍光を発する顆粒が存在することを 発見し, この起源を追跡した結果, より微細なクリプ 卜藻を取り込むことを観察した。従属栄養あるいは取 り込んだ色素を利用した光合成を行っているものと推 定している。

\section{3 下痢性貝毒成分の構造と分析法}

安元らの研究で毒化二枚貝から10種以上の有毒成分 が発見されている12)。すべてポリエーテル化合物であ り，骨格構造から 3 種の同族体に分けられる(図 4)。 初めて単離された下痢性貝毒はディノフィシストキシ ン-1（DTX1）であるが，海綿抒よび底生の渦鞭毛藻 Prorocentrum limaから分離されていたオカダ酸 (OA)の35位メチル体であることが明らかになった。 のちにオカダ酸も毒化二枚貝から検出され，下痢性貝 毒であることが示された。7位に脂肪酸エステルを有 するディノフィシストキシン-3(DTX3)を含め, 末端 にカルボン酸を有するこのグループは, 強い下㢉原性 を有し，中毒症状の主原因と考光られている。また， ホタテガイからは同一骨格を有し，43位の酸化状態の 又異なるペクテノトキシン (PTX) 群が単離, 構造決 

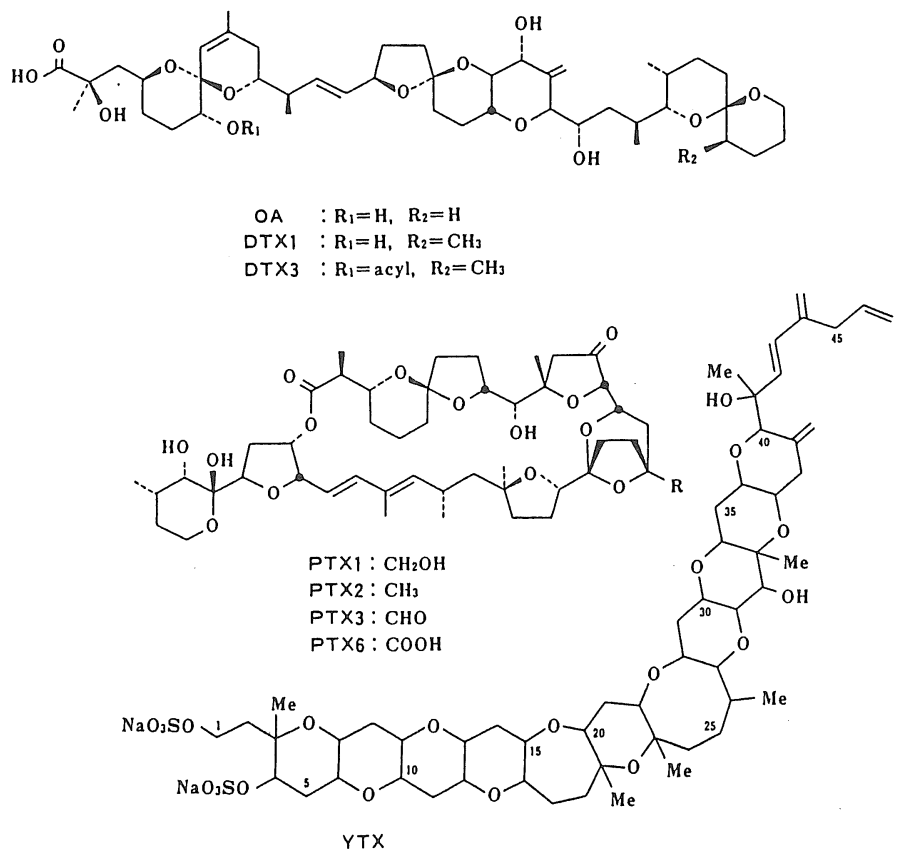

図 4 下痢性貝毒の構造

DTXはディノフィシストキシン，OAはオカダ酸，PTXはペクテノトキシン，YTXはイェソトキシンを示す。

定されている。強い肝臓毒性が認められることから慢 性毒性に懸念が持たれて扔り，看過できない成分であ る。また，第三のグループとしてイェソトキシン (YTX) が明らかにされているがその起源は不明であ る。

食品中の下痢性貝毒の監視はマウス毒性試験法に よって行われている。下痢性貝毒は，多様な構造を有 する複成分系であるので，麻㿁性貝毒に怙けるような すべての成分を検出できる化学的分析法の適用は不可 能である。ディノフィシストキシン群については，末 端付近のカルボン酸を利用して, 9-anthryldiazomethane で蛍光ラベル化して高速液体クロマトグラフィー で検出する方法が開発され，さきに述べた原因種の特 定のみならず，一部貝毒監視に実用されている ${ }^{13)}$ 。ま た, 同群については酵素免疫定量法も開発され, 一部 の検体については, 毒の定量が迅速から簡便に行らこ とができるようになった ${ }^{14)}$ 。

\section{4. 神経性貝毒}

アメリカのフロリダ, メキシコ湾沿岸では渦鞭毛藻 Gymnodinium breve (=Ptychodiscus brevis) の赤潮 が頻発している。この渦鞭毛藻赤潮は魚類をはじめと する海洋生物のへい死を引き起こすが，ときに二枚貝 に蓄積され食中毒の原因となることもある。酒に酔っ
た感じや運動失調を伴らことから，神経性貝中毒 (neuro shellfish poisoning) と呼ばれる。また，風に 乗った飛沫に含まれる毒により気管支系の障害も問題 となっている。原因毒はブレベトキシン群と呼ばれ， ポリエーテル系化合物で，これも多数成分が発見され ている。食中毒よりも一般の赤潮毒としての被害が大 きいので詳しい説明は別章に譲る。な拉，日本でも同 属の G. nagasakiense による赤潮が頻発しているが, ブレベトキシンは検出されていない。

\section{5. 健忘性貝毒}

1987年の11月から12月にかけて，カナダのセント ローレンス湾のプリンスェドワード島産のムラサキイ ガイで106名の中毒患者が発生し，3 名が死亡した。高<smiles>C/C(=C/C=C/C(C)C(=O)O)[C@H]1CNC(C(=O)O)[C@H]1CC(=O)O</smiles>

図 5 ドーモイ酸の構造 
齢者に重症者が多く，かつ，記憶喪失が顕著であった ので amnesic shellfish poisoning と命名された。ここ では健忘性貝中毒と仮称することにする。麻痺性貝毒 生物試験法を適用すると, 異なる症状を呈してマウス が死亡した。この毒性を指標に急遽中毒原因物質の探 索が行われ，さきに紅藻ハナヤナギから駆虫物質とし て単離されていたドーモイ酸(図 5 )が同定された。毒 化原因種についても検索が行われ，当時高密度で発生 していた硅藻中の Nitzschia pungens の培養藻体から ドーモイ酸が検出された。有毒の硅藻は極めて珍しい が, Nitzschia は各地で一般的にみられる硅藻であり, 日本近海でもドーモイ酸を生産する種類が分布するか どうか早急に調査する必要があろう。

\section{6.おわりに}

以上に紹介したように, 貝毒には近年顕在化したり 毒化域の拡大した例が多く，赤潮被害と対比される。 しかし，麻痺性貝毒のように工業が発達する以前から 知られたものや優占種とは言えない汪どの低密度の原 因種の出現で毒化が起こる例が多く，単純に人間の社 会活動，とくに沿岸の富栄養化とは結びつかない面が ある。顕在化した理由としては(1)分析法の発達，(2)監 視網の細密化，(3)二枚貝養殖技術の発達による漁場の 拡大やホタテガイなどの垂下養殖に見られるよらな漁 業形態の変化，(4)夏期にも二枚貝が大量に流通するな ど消費形態の変化も考学られる。

これまで述べてきたように貝毒の原因生物に関する 研究では, 微量かつ複雑な化合物の検出, 定量法の開 発が不可欠であり, 今後も化学者と生物学者の緊密な 連携が必要とされる。

\section{文献}

1 ) 福代康夫編 (1985) 貝毒プランクトン一生物学と生態学, 125 pp., 恒星社厚生閣, 東京.

2) Fukuyo Y., Yoshida K., Ogata T., Ishimaru T., Kodama M., Pholpunthgin P., Wisessang S., Phanichakarn P. and Piyakarnchana T. (1989) Suspected causative dinoflagellates of paralytic shellfish poisoning in the gulf of Thailand, In Red Tides-Biology, Environmental Science and Toxicology, pp.403-406, Elsevier, New York.

3 ) Oshima Y., Hasegawa M., Yasumoto T., Hallegraeff G. and Blackburn S. (1987) Dinoflagellate Gymnodinium catenatum as the source of paralytic shellfish toxins in
Tasmanian shellfish. Toxicon, 10, 1105-1111.

4) Ikeda T., Matsuno S., Sato S., Ogata T., Kodama M., Fukuyo Y. and Takayama H. (1989) First report on paralytic shellfish poisoning caused by Gymnodinium catenatum Graham (Dinophyceae) in Japan, In Red Tides-Biology Environmental Science and Toxicology, pp.411-414, Elsevier, New York.

5 ) Oshima Y., Sugino K., Itakura H., Hirota M., and Yasumoto $\mathrm{T}$. (in press) Comparative studies on paralytic shellfish toxin profiles of dinoflagellates and bivalves, In Toxic Marine Phytoplankton, pp.391-396, Elsevier, New York.

6) Hallegraeff G., Steffensen D.A. and Wetherbee R. (1988) Three estuarine Australian dinoflagellates that can produce paralytic shellfish toxins. J. Plankton Res., 10, 533-541.

7) Matsuoka K., Fukuyo, Y. and Gonzales C.L. (1989) A new discovery of cysts of Pyrodinium bahamense var. compressa from the Samar Sea, Philippines, In Red Tides-Biology, Environmental Science and Toxicology, pp.301-304, Elsevier, New York.

8 ) Kodama M., Ogata T. and Sato S (1989) Saxitoxinproducing bacterium isolated from Protogonyaulax tamarensis, In Red Tides-Biology, Environmental Science and Toxicology, pp.363-366, Elsevier, New York.

9) Kotaki Y., Tajiri M., Oshima Y. and Yasumoto T. (1983) Identification of a calcareous red alga as the primary source of paralytic shellfish toxins in coral reef crabs and gastropods, 日本水産学会誌, 49, 283-286.

10) Oshima Y., Sugino K. and Yasumoto T. (1989) Latest advances in HPLC analysis of paralytic shellfish toxins, In Mycotoxins and Phycotoxins '88, pp.319-326, Elsevier, New York.

11) Yasumoto T., Oshima Y. and Yamaguchi M. (1978) Occurrence of new type of shellfish poisoning in the Toho$\mathrm{ku}$ District. 日本水産学会誌, 44, 1249-1255.

12) 安元 健, 村田道雄(1988) 新編生物活性天然物質, 170 (1988), 医歯薬出版。

13) Lee J.S., Murata M. and Yasumoto T. (1989) Analytical methods for determination of diarrhetic shellfish toxins. In Mycotoxins and Phycotoxins '88, pp.327-334, Elsevier, New York.

14) Uda, T., Itoh, Y., Nishimura, M., Usagawa, T., Murata, M. and Yasumoto, T. (1979) Enzyme immunoassay using monoclonal antibody specific for diarrhetic shellfish poisons, In Mycotoxins and Phycotoxins '88, pp.335-342, Elsevier, New York. 